\title{
Research
}

\section{Exploring the Promise of Actor Analysis for Environmental Policy Analysis: Lessons from Four Cases in Water Resources Management}

\author{
$\underline{\text { Leon M. Hermans }}^{1}$
}

\begin{abstract}
A persistent challenge for the development of well-informed and sound environmental policies is to improve the connection between environmental experts, decision makers, and other involved actors. Answers are sought in processes for social learning and adaptive co-management that engage experts, decision makers, and local actors in an interactive way of policy making. The preparation and organization of such interactive processes is usefully supported by actor analysis, which can help to identify the main actors to be involved in environmental policy making, to locate useful local knowledge, to identify potential conflicts, and to assess the feasibility of different policy measures. I explored the promise that actor analysis holds to support environmental experts in environmental policy analysis activities. I present and discuss the findings from four cases in water resources management. These findings are counterintuitive in that they suggest that environmental experts are more reluctant to use the insights provided by actor analysis than one would expect based on their frequently expressed desire to improve their connection with decision makers. Therefore, I conclude with a discussion of three mechanisms that might explain these findings, as well as their consequences for the future use of actor analysis in environmental policy analysis.
\end{abstract}

Key Words: actor analysis; environmental policy; policy analysis; stakeholder analysis; water resources management

\section{INTRODUCTION}

Environmental experts regularly express their concern over the fact that their knowledge and understanding is insufficiently used by decision makers and managers to support natural resources management in practice. Concerns over the gap between experts and decision makers were evident in the 1970s, when an international expert workshop identified the need to address the "abyss presently separating technical impact assessment studies from actual environmental planning and decision making" (Holling 1978: xv), and in the 1990s, when the inaugural issue of Ecology and Society addressed the issue of "useable knowledge" (Baskerville 1997, Franklin 1997, Fujii 1997, Gallopin 1997, Levin 1997, Pulliam 1997, Walker 1997, Wiens 1997). They are still evident in the 21st century, with the need to bridge the "sciencemanagement divide" (Roux et al. 2006).

Especially for experts involved in environmental policy analysis, the persistence of this gap is of serious concern. These experts spend considerable time and effort to develop and give advice on policies that should ensure the sustainable management of natural resources, only to see that their advice is not taken by decision makers or, when it is translated into official policy, that the policies are not implemented. Therefore, various strategies have been proposed to improve the connection between environmental experts, decision makers, and the wider range of actors. One of the most widely recognized strategies is to involve the participants jointly in a participatory process of social learning and adaptive co-management (International Council for Science 2002, Gunderson and Light 2006, Pahl-Wostl 2006, Roux et al. 2006).

Such an open process requires effort from all participants involved. For instance, decision makers should be more aware and more receptive of expert knowledge and advice, and experts should do more to frame their knowledge and analysis in a way that is useable by decision makers (Wildavsky 1979, Baskerville 1997). This requires experts to find out 
the main concerns of decision makers and local actors and how they should position themselves to ensure that their analytical activities fit the demands of the policy-making process (Wildavsky 1979, Forester 1989, de Bruijn and ten Heuvelhof 2002, van de Riet 2003).

There are several methods available to support experts in studying the characteristics of actors and policy networks. Stakeholder analysis, which is rooted in strategic management literature and described, for instance, by Grimble and Wellard (1997) and Bryson (2004), is probably the most widely used method in environmental management, but there are more useful methods available. These include methods to analyze the structure of social networks (Scott 2000, Carrington et al. 2005), methods to map actor perceptions and values (Bots et al. 2000, Stone 2002, Mouratiadou and Moran 2007), and methods to assess and analyze conflicts between actors (Howard 1989, Hjortso et al. 2005, Kilgour and Hipel 2005). Compared to the relatively simple methods for stakeholder analysis, these methods offer somewhat more sophisticated analytical support without requiring an in-depth academic investigation. This makes them interesting for environmental policy analysts. Because the collection of suitable methods is not limited to methods for stakeholder analysis only, I refer to them as actor analysis methods to avoid confusion with the more limited notion of stakeholder analysis methods as they are generally conceived.

Various authors have suggested that the insights that can be obtained with the use of these actor analysis methods provide an important building block in the preparation of participatory policy processes. For instance, actor analysis helps to identify the actors that should be involved and sheds light on possible roles of different actors, as well as some of the opportunities and risks associated with involving these actors (Mostert 2003, Bryson 2004, PahlWostl 2006). Also, actor analysis can help to identify the concerns, objectives, and priorities of different actors and to mobilize relevant knowledge from a broad actor base (Grimble and Wellard 1997, Borsuk et al. 2001, van de Riet 2003, Bryson 2004). Furthermore, information from an actor analysis provides useful insight into the feasibility and implementability of policy measures based on interests, potential conflicts, and influences of various actors (Grimble and Wellard 1997, Brugha and Varvasovszky 2000, Bryson 2004).
Despite this potential of actor analysis to support environmental experts in their effort to produce useable knowledge, few reports are available on its contributions in practice. The actor analysis studies that are reported generally make a case for the usefulness of a certain approach by showing that it yields information that is believed to be useful, without scrutinizing its actual effects on policy analysis or policy-making processes (Borsuk et al. 2001, Kontogianni et al. 2001). Other researchers discuss the usefulness of actor analysis only in general terms (Brugha and Varvasovszky 2000, Stone 2002) or acknowledge that the actual contributions of actor analysis remain ill understood and are insufficiently backed by empirical evidence (Grimble and Wellard 1997, Bryson 2004). There is no empirical base of evidence that is sufficiently detailed to allow for meaningful reflection on the contributions that actor analysis can make to improve the connection between environmental experts and decision makers. In the absence of such evidence, the claims regarding the usefulness of actor analysis in environmental policy analysis can not be considered demonstrated knowledge, but have the status of promises yet to be fulfilled. Here, I explore the promise of actor analysis for environmental experts who want to support policy making by asking the question: How is actor analysis used by environmental experts to ensure that their environmental policy analysis is useful for decision makers?

\section{METHODS}

\section{Action research on environmental policy analysis projects}

To address the question posed above requires empirical data on the use of actor analysis by environmental experts. Because most of the existing literature in the field neglects this aspect or treats it in insufficient detail, additional data collection is necessary. One option to obtain additional empirical data would be to review past applications of actor analysis and assess their usefulness in the support of environmental experts in practice, including their effects on the policy analyses performed and recommendations given by those experts. Another option would be to use an action research approach in which an actor analysis is applied and its effects are subsequently monitored. I used the second approach, mainly because it would improve the understanding of the local context and conditions in 
each of the researched cases. Such familiarity and insight into case-specific circumstances is valued because it is an essential requirement for trustworthy qualitative analysis (Campbell 1988).

I used four cases to assess the practical use of actor analysis for environmental experts who want to contribute knowledge and analysis to support decision makers. An actor analysis was conducted for ongoing environmental policy analysis projects in the period between 2000 and 2003, according to the state-of-the-art insights on actor analysis that were available from literature and previous experience. Following the execution of the actor analysis, the results were translated into conclusions and recommendations for the project and were presented and discussed with the environmental experts and the main actors involved.

The cases that I used reflect the variety of situations in which environmental experts can find themselves when working as policy analysts. However, each case was required to meet some specific conditions to ensure a certain degree of comparability across cases. Each of the four cases consisted of an environmental policy analysis project in which experts aimed to provide sound and useful information to support decision makers. Each of these ongoing projects had a time span of several years and involved several experts, making the addition of an actor analysis a reasonable effort relative to the size of the project. Also, for each case, the experts involved expressed a genuine interest in the use of actor analysis through the commitment of project resources and staff time to support the execution of the actor analysis. Thus, the actor analysis should not have been considered merely window-dressing for the project. A thematic focus was maintained within the broader area of environmental policy analysis by using only cases in the field of water resources management. Finally, although the cases involved international projects in different locations, some Dutch expertise was always involved. This was a consequence of the practical consideration of the availability of cases.

\section{Procedure for the execution of case studies}

I used the action research approach to conduct an actor analysis for each case, in close cooperation with the environmental experts involved. The basis for the execution of the actor analysis was formed by the general procedure and practical guidelines for actor analysis as outlined by Hermans (2005). These procedural guidelines were combined with the use of specific analytical methods to strengthen the analytical quality of the analysis in a way that matched the specific circumstances in each case. The latter methods included methods for argumentative analysis (Toulmin 1958, Dunn 1993), conflict analysis (Howard 1989), and comparative cognitive mapping (Bots et al. 2000).

The purpose of the actor analysis was established with input from the environmental experts involved; based on the agreed purpose and a preliminary scan of the actor network and the data collection environment, a suitable method for actor analysis was selected. Data were then collected using interviews with actor representatives as primary sources of information, complemented by secondary literature and information from knowledgeable outsiders. The actor representatives comprised a mix of decision makers and professionals from government organizations and civil society, including key government ministries, nongovernmental organizations, private sector representatives, and local and/or regional administrations such as municipalities and/or governorates. I conducted the interviews, during which I was generally accompanied by a local expert of the project team. For each interview, an interview report was made and sent to the interviewees for verification and validation. Based on these interview reports, data were structured according to the format prescribed by the selected analysis method, after which results were interpreted and translated into conclusions and recommendations for use in the environmental policy analysis projects. The results were presented to the environmental experts involved in the projects by means of a written report; an oral presentation of findings was made to the wider group of actors as part of a project workshop or stakeholder meeting. Only the general outcomes of the actor analyses for these four cases are described here; further details can be found in Hermans et al. (2002) and Hermans (2003, 2004, 2005).

The actor analysis for each case was evaluated for analytical success and utilization success (Goeller 1988). These evaluations were performed between four and twelve months after the actor analysis had been finalized and presented. Information was provided by the involved environmental experts, who were the intended users of the actor analysis. Their responses were complemented by and cross- 
checked with project documents that were produced prior to and after the actor analysis. Analytical success was assessed by identifying the analytical output of the actor analysis that was credible, relevant, and new (Goeller 1988). Utilization success was assessed by asking the involved experts to review the effects of the actor analysis on their work. Here, the distinction between substantive analysis and interaction processes in policy analysis (e.g., Scharpf 1997) was used to categorize the different uses of actor analysis for the environmental policy analysis projects.

\section{BACKGROUND AND PURPOSE OF ACTOR ANALYSIS IN THE SELECTED CASES}

\section{National Water Resources Plan project, Egypt}

The first case to which an actor analysis was applied was a 4-yr project (1998-2002) to support the development of a national water resources plan for Egypt for the period until 2017 (Table 1). The project implementation was done by a team of Egyptian water engineers from the Ministry of Water Resources and Irrigation, supported by a consortium of Dutch experts from research institutions, engineering consultancies, and Dutch national government. In the project's first years, the development of various hydraulic, hydrological, and water quality simulation models played an important role. The project also recognized the importance of the political and procedural aspects of drafting a policy document and initiated three committees to involve the important actors early in the process. Through these committees, representatives of various ministries were kept informed of the project's progress and had the opportunity to contribute to the analysis activities. Nevertheless, achieving the real involvement of all actors in the policy analysis process proved to be a difficult challenge.

The actor analysis was executed in the spring of 2001, when the project had finished the initial model development and was entering a new phase of strategy formulation in which the emphasis was to shift toward the procedural aspects of drafting a policy document. The actor analysis was intended to support this transition by linking the different water policy options and their consequences to the objectives of the actors. Insight into the issues in which the actors were interested and the objectives that influenced their behavior would help to identify the relevant trade-offs in developing a water policy. Actor analysis was also expected to help the experts to assess the influence that different actors might have on water resources management by taking stock of their interests, means, and resources.

\section{Diffuse pollution in North Holland, the Netherlands}

The second case was an actor analysis for the development of a management plan for 2002-2005 to address diffuse sources of water pollution in the province of North Holland, the Netherlands (Table 1). This plan development was done by the Regional Project Organization for Diffuse Pollution in North Holland, a body in which the different government agencies that are involved in water quality management coordinate their activities. The activities were executed by a project group that consisted of the water policy advisors of the various government agencies. In 2001, the Project Organization commissioned a "polluting sources" study in which the main pollutants and their sources were to be identified based on monitoring data and estimations. Along with this physical picture of water quality and pollution loads, the actor context also needed to be considered because the cooperation of other actors would be critical to accomplish a reduction in pollution.

The actor analysis was intended to help in understanding the perceptions of the various actors and to identify promising ways in which the actors could be motivated and supported to reduce diffuse pollution. Specifically, the actor analysis could provide recommendations on how to start a fruitful dialog among the various actors involved. Another purpose of the actor analysis for the Project Organization was to learn more about the perspectives of the decision makers in its various member organizations. It seemed that sometimes the staff representatives gave personal statements during the meetings of the project organization, but that they were rather isolated within their own organizations. Therefore, the representatives considered it useful to gain more insight into the priorities and perceptions of the different decision makers that were involved. 
Table 1. Overview of the case characteristics.

\begin{tabular}{ll}
\hline \hline Case & Project focus \\
\hline $\begin{array}{l}\text { National Water Resources } \\
\text { Plan project, Egypt }\end{array}$ & $\begin{array}{l}\text { Preparation of a national water } \\
\text { resources management policy }\end{array}$ \\
$\begin{array}{l}\text { Diffuse pollution in North } \\
\text { Holland, the Netherlands }\end{array}$ & $\begin{array}{l}\text { Preparation of a provincial } \\
\text { water quality management plan }\end{array}$ \\
$\begin{array}{l}\text { River basin planning pilot } \\
\text { project for Büyük Menderes } \\
\text { basin, Turkey }\end{array}$ & $\begin{array}{l}\text { Preparation of a river basin } \\
\text { management plan in line with } \\
\text { the European Union's Water }\end{array}$ \\
& Framework Directive \\
$\begin{array}{l}\text { Water Resources } \\
\text { Management through } \\
\begin{array}{l}\text { Integrated Development } \\
\text { project, Central Cebu, the } \\
\text { Philippines }\end{array}\end{array} \quad \begin{array}{l}\text { Development of a regional } \\
\text { water resources management } \\
\text { strategy and implementation of } \\
\text { water conservation }\end{array}$
\end{tabular}

Purpose of actor analysis

Support the project in beginning a new phase of strategy formulation

Complement technical analysis with attention to policy implementation

Support the project through an exploration of the actor environment and the identification of issues to be included in the plan's development

Support the project through the formulation of specific research questions and the organization of actor involvement
Actor analysis method

Metagame analysis

(Howard 1989)

Dynamic actor network analysis

(Bots et al. 2000)

Dynamic actor network analysis

(Bots et al. 2000)

Argumentative analysis (Toulmin 1958, Dunn 1993) and analysis of options (Howard 1989)

\section{River basin planning pilot project for the Büyük Menderes basin, Turkey}

The third case concerned the participatory development of an integrated river basin management plan for the Büyük Menderes river basin as part of a pilot project to support the introduction of the European Union's Water Framework Directive in Turkey (Table 1). To prepare the river basin management plan, a regional working group was formed that consisted of representatives of relevant government agencies in the river basin. The project team, which comprised experts from a Dutch-Turkish consortium of research and training institutes and engineering consultancies, would provide expert advice and training to the members of the regional working group and help them through the steps for the establishment of a river basin management plan in line with the requirements of the Water Framework Directive. The actor analysis was carried out early in the project, in 2002, and preceded the first project workshop in the Büyük Menderes river basin.

The main purpose of the actor analysis was to support the development of a widely recognized problem formulation that could provide a good basis for the participatory development of a River Basin Management Plan. As such, the actor analysis was expected to provide insight into the main problems and solutions according to the various actors, the actors' main interests and objectives, the areas of agreement and disagreement, the priority of issues to be addressed in the regional pilot project, and ideas on how to structure the participation of actors in the development of a River Basin Management Plan. In addition, the actor analysis was expected to provide insight into the existing institutional structure in the region and into the training needs to be addressed by the project team.

\section{Central Cebu Water Resources Management through Integrated Development project, the Philippines}

The final case was the Central Cebu Water Resources Management through Integrated Development (or Water REMIND) project in the Philippines (Table 1). The purpose of this 5-yr project was to 
support the development of a water resources management strategy in the Central Cebu region while at the same time supporting the implementation of some promising pilot activities to explore possibilities for practical improvements. The implementation of the project was led by a local expert center in water resources research and involved a local stakeholder platform focused on water management and local government organizations. The local center was supported by water experts from Dutch research institutes.

Early in the project, in February 2003, an actor analysis was executed to support the project team in developing an agenda for analysis activities and pilot projects. The purpose of the actor analysis was to identify the relevant water management questions according to the actors involved and how these questions could be addressed in the project, including through its pilot projects. The actor analysis was also expected to support the involvement of the actors in the project from an early stage. The results of the actor analysis were expected to help the experts to determine which solutions were promising for further research, which issues were most controversial, and who were considered the critical actors, as well as opportunities for joint gains among the actors.

\section{ANALYTICAL SUCCESS OF THE ACTOR ANALYSES}

\section{Output with implications for substantive analysis by environmental experts}

In all cases, the involved experts expressed their appreciation for the insight and overviews produced by the actor analysis. The actor analysis usually partly confirmed what was already expected, but also offered some new insight. The project experts identified the new, credible, and relevant output of the actor analyses for substantive problem analysis (Table 2). This output could help the project experts to frame their analysis activities in a way that would be in closer alignment with the needs and questions of decision makers and other actors in the policy process.

There was new insight related to three types of potential use for actor analysis. First, the actor analysis identified issues that appeared to be important, but that were not considered in the initial problem formulation. For instance, in the Dutch case, various decision makers made clear that they were interested mainly in integrated water quality management plans that considered point-source pollution in addition to diffuse pollution. Second, some output helped to indicate parts of the initial problem formulation that should receive more emphasis. For instance, in the Turkish case, many actors were concerned about one specific type of pollution that is associated with boron released by geothermal sources, which would warrant more specific attention early in the analysis. Third, useful information surfaced about the various actors; this information fit with the initial problem formulation, adding more detail or specific information from a multiactor perspective. For instance, the actor analysis results in the Egyptian case showed some of the interdependencies among actors and some of the potentially conflicting policy positions. This information was new to the project, partly because the actor consultations thus far had resulted in a wish list of policy options, with little or no attention to their implementation and consequences.

\section{Output with implications for the organization of interaction processes}

The project experts also identified the new, credible, and relevant implications for interaction processes (Table 3). The actor analysis identified the main actors that should be involved in the projects and also offered a motivation for their involvement. In two of the four cases, i.e., the Netherlands and the Philippines, the actor analysis indicated the need to involve actors who had been absent from the policy analysis process up to that moment. In these two cases, the project experts organized their activities mainly around the problem owners, excluding the actors who were considered to be (partially) causing the problems. However, the cooperation of these actors would be essential to address the problems.

The actor analysis identified actors and reasons for their involvement. It did not offer detailed blueprints for the design of interaction processes, but identified participants and agenda items for discussion. These agenda items generally matched the issues that were also suggested for inclusion in the problem formulation, for example, the issue of boron pollution in Turkey and the interdependencies among actors and the costs and benefits of water policy options in Egypt. In addition, in the Turkish and Philippine cases, useful insights were obtained into the current levels of awareness of the involved 
Table 2. Actor analysis output that had implications for substantive problem analysis.

\begin{tabular}{llll}
\hline \hline Case & $\begin{array}{l}\text { Expand the scope of the initial } \\
\text { problem formulation }\end{array}$ & $\begin{array}{l}\text { Adjust the importance of } \\
\text { components in the initial } \\
\text { problem formulation }\end{array}$ & $\begin{array}{l}\text { Describe parts of the problem } \\
\text { related to actors }\end{array}$ \\
\hline $\begin{array}{l}\text { National water } \\
\text { resources plan, } \\
\text { Egypt }\end{array}$ & $\begin{array}{l}\text { Need to specify costs and } \\
\text { benefits of options }\end{array}$ & $\begin{array}{l}\text { Importance of ongoing } \\
\text { institutional reform debate }\end{array}$ & $\begin{array}{l}\text { Policy options as viewed by } \\
\text { actors; interdependence among } \\
\text { actors }\end{array}$ \\
$\begin{array}{l}\text { Diffuse pollution, } \\
\text { Netherlands }\end{array}$ & $\begin{array}{l}\text { Need to integrate diffuse } \\
\text { pollution with point-source } \\
\text { pollution in policy analysis }\end{array}$ & $\begin{array}{l}\text { Decision makers' and experts' } \\
\text { priorities for pollution reduction } \\
\text { differ }\end{array}$ & $\begin{array}{l}\text { Articulation of tacit knowledge } \\
\text { need for better communication; } \\
\text { motivations and rationale of } \\
\text { polluters }\end{array}$ \\
$\begin{array}{l}\text { River basin } \\
\text { planning, Turkey }\end{array}$ & $\begin{array}{l}\text { Need to address water scarcity in } \\
\text { addition to water quality }\end{array}$ & $\begin{array}{l}\text { Perceived importance of boron } \\
\text { pollution; problems perceived at } \\
\text { both institutional and operational } \\
\text { levels }\end{array}$ & $\begin{array}{l}\text { Level of expertise and } \\
\text { coperation among local actors; } \\
\text { nof actors regarding a }\end{array}$ \\
$\begin{array}{l}\text { Regional water } \\
\text { management, Phi- } \\
\text { lippines }\end{array}$ & $\begin{array}{l}\text { Need to address equity issues } \\
\text { and the use of economic } \\
\text { mechanisms in water } \\
\text { management }\end{array}$ & $\begin{array}{l}\text { Three main groups are important } \\
\text { for water management, but one } \\
\text { of these is currently excluded } \\
\text { from the debate }\end{array}$ & $\begin{array}{l}\text { Actors' perspectives on water } \\
\text { management are grouped into } \\
\text { three main categories; level of } \\
\text { awareness of actors for water } \\
\text { management issues }\end{array}$
\end{tabular}

actor representatives, helping the involved experts to assess the need for educational and training activities as part of their projects.

\section{UTILIZATION SUCCESS OF THE ACTOR ANALYSES}

The actor analysis output was potentially useful for the environmental policy analysis projects because it was considered to be credible, relevant, and new by the projects' experts. Some of the output even seemed to be critical to the eventual success of the projects in addressing real-world problems in a way that would be accepted by all of the important actors. I examined the extent to which the project experts used this potentially useful analytical output to improve their analysis activities and to organize the interactions among the main actors in the policy environment.

\section{Main observed effects per case}

I summarized the use of the actor analysis output using the distinction between substantive analysis and the interaction process and also listed some contributions of actor analysis to general learning on the policy environment of projects that are highly likely to have had indirect effects (Table 4). Relatively few direct effects of the actor analysis on the substantive analysis activities could be established. The most promising cases in this regard were those in Egypt and the Netherlands, for which project development that was in line with the actor analysis recommendations was observed. However, in both cases, it was difficult to attribute these developments solely to the effect of the actor analysis. There were other developments that may have played a more influential role in the decisions to change analysis activities. For instance, in the Netherlands, the actor analysis resulted in the recommendation to include point sources of pollution in the analysis, in addition to diffuse sources. Nevertheless, the project focus initially remained on diffuse pollution only. When more than one year later the focus was broadened to include 
Table 3. Actor analysis output that had implications for the interaction process.

\begin{tabular}{|c|c|c|}
\hline Case & Whom to involve and why & How to involve actors and what to discuss \\
\hline $\begin{array}{l}\text { National water } \\
\text { resources plan, } \\
\text { Egypt }\end{array}$ & $\begin{array}{l}\text { Identified the need to involve actors because of } \\
\text { interdependencies, e.g., the ability of actors other } \\
\text { than Ministries of Water Resources and Irrigation } \\
\text { and of Agriculture to influence water management }\end{array}$ & $\begin{array}{l}\text { Discuss actors' positions and responsibilities } \\
\text { related to costs and benefits of water management } \\
\text { options; link parts of discussion to broader } \\
\text { institutional reform debate }\end{array}$ \\
\hline $\begin{array}{l}\text { Diffuse pollution, } \\
\text { Netherlands }\end{array}$ & $\begin{array}{l}\text { Identified the need to involve actors who have } \\
\text { control over the problem instead of only problem } \\
\text { owners, starting with municipalities and the } \\
\text { private sector }\end{array}$ & $\begin{array}{l}\text { Discuss both diffuse and point-source pollution } \\
\text { issues in the same platform }\end{array}$ \\
\hline $\begin{array}{l}\text { River basin } \\
\text { planning, Turkey }\end{array}$ & $\begin{array}{l}\text { Identified individual actor representatives to } \\
\text { participate in project training and planning } \\
\text { activities }\end{array}$ & $\begin{array}{l}\text { Discuss boron pollution and operational problems } \\
\text { use existing structures, rather than a new river } \\
\text { basin authority; start training at a more advanced } \\
\text { level }\end{array}$ \\
\hline $\begin{array}{l}\text { Regional water } \\
\text { management, Phi- } \\
\text { lippines }\end{array}$ & $\begin{array}{l}\text { Identified the need to involve three types of actors, } \\
\text { including a group of private-sector actors that are } \\
\text { currently excluded from the debate, because all } \\
\text { groups control parts of the problem }\end{array}$ & $\begin{array}{l}\text { Educate some of the actors on substantive water } \\
\text { issues }\end{array}$ \\
\hline
\end{tabular}

both point-source pollution and diffuse pollution, this change was more likely related to discussions among decision makers and developments at the national level than to the output of the actor analysis.

With regard to the interaction process among project experts, decision makers, and other actors, two different types of contributions could be observed. In the cases in Turkey and the Philippines, the actor analysis made a very practical contribution by simply starting up the interaction process through interviews and workshops. Although it is not clear that these contributions required the use of specific actor analysis methods, it is clear that they were useful for the projects. In the cases in Egypt and the Netherlands, for which interaction processes had already been established, the effects of the actor analysis were less visible. The experts' responses suggest that in these cases, the actor analyses caused project experts, decision makers, and other key actors to reflect on their roles, thus aiding a reflective process that eventually led to improvements in the organization of the interaction process.

Finally, the actor analysis allowed the projects' experts to learn about the perceptions of other actors.
It offered some of the experts a new perspective from which to view water policy development. Such general learning is likely to have had some indirect effects on the attitude and work of the environmental experts.

\section{Summary: utilization success or failure?}

The summary of the effects of actor analysis in the cases suggests a mixed record for the utilization success of actor analysis. The direct effects that could be attributed to the actor analysis were modest, particularly for the analytical activities of the projects' experts. The findings can be summarized in one or two sentences that characterize the main use of the actor analysis as evaluated by the projects' experts (Table 5). It is clear that the main use of the actor analysis output was related to general learning and to a confirmation of knowledge that was already present within the project or that emerged simultaneously from other sources. Although this does not make the actor analysis useless, it is a rather disappointing result in light of the initial expectations based on the current literature regarding actor analysis. 
Table 4. Use of the actor analysis: effects of the actor analysis on project activities.

\begin{tabular}{|c|c|c|c|}
\hline Case & Substantive analysis & Interaction process & $\begin{array}{l}\text { General learning and indirect } \\
\text { effects }\end{array}$ \\
\hline $\begin{array}{l}\text { National water } \\
\text { resources plan, } \\
\text { Egypt }\end{array}$ & $\begin{array}{l}\text { Helped to generate more } \\
\text { attention to the costs of policy } \\
\text { options and institutional reform }\end{array}$ & $\begin{array}{l}\text { Helped to clarify roles and } \\
\text { responsibilities in project } \\
\text { committees }\end{array}$ & $\begin{array}{l}\text { Introduced a new perspective on } \\
\text { interdependencies among actors }\end{array}$ \\
\hline $\begin{array}{l}\text { Diffuse pollution, } \\
\text { Netherlands }\end{array}$ & $\begin{array}{l}\text { Helped to integrate diffuse and } \\
\text { point-source pollution }\end{array}$ & $\begin{array}{l}\text { Helped to expand the type of } \\
\text { actors involved; triggered } \\
\text { reflection on the roles of actors in } \\
\text { diffuse pollution policy }\end{array}$ & $\begin{array}{l}\text { Enabled learning about the } \\
\text { perceptions of others }\end{array}$ \\
\hline $\begin{array}{l}\text { River basin } \\
\text { planning, Turkey }\end{array}$ & Few direct effects & $\begin{array}{l}\text { Helped to start the interaction } \\
\text { process and to prepare the first } \\
\text { workshop and training of local } \\
\text { actors }\end{array}$ & $\begin{array}{l}\text { Enabled learning about a largely } \\
\text { new and unknown project } \\
\text { environment }\end{array}$ \\
\hline $\begin{array}{l}\text { Regional water } \\
\text { management, } \\
\text { Philippines }\end{array}$ & $\begin{array}{l}\text { Initiated effort to take into } \\
\text { account concerns and solutions } \\
\text { from three main actor groups }\end{array}$ & $\begin{array}{l}\text { Initiated effort to include actors } \\
\text { from all three groups in project } \\
\text { activities; provided a basis for the } \\
\text { first stakeholder workshop }\end{array}$ & $\begin{array}{l}\text { Enabled learning and updating of } \\
\text { knowledge about perceptions and } \\
\text { awareness of actors }\end{array}$ \\
\hline
\end{tabular}

Of course, the use of the actor analysis output was not straightforward and required quite some effort, especially when the output required the project experts to broaden the scope of their activities or to engage in a more participatory analysis process. Also, each case had some specific circumstances that could help to explain the limited use of the actor analysis output in that particular case (Table 5). It was difficult to assess the contribution of the actor analysis output to subsequent changes in project activities, and there may have been useful indirect effects. Nevertheless, the expectations that were formulated by the environmental experts that were involved at the beginning of each case and the analytical success of the actor analyses led to the expectation of substantial evidence of utilization success in at least some of the four cases examined.

\section{REASONS WHY EXPERTS DO NOT USE THE OUTPUT OF ACTOR ANALYSIS}

\section{Discussion of the main finding: analytical success, but limited use of output}

Time and again, environmental experts express dissatisfaction with the fact that decision makers seem to make scant use of their knowledge and expertise in deciding upon environmental policies and their implementation. They also express a desire to close the gap between themselves and decision makers, not only in informal conversations, but also in official reports and academic journals (see Introduction). Even if it is recognized that the gap cannot be closed by experts alone, they surely are part of the problem and are clearly bothered by the problem. Thus, one can reasonably expect that environmental experts would welcome recommendations upon which they could act to decrease the gap in specific policy analysis projects.

If this is so, how can the negative case findings be explained? Is it possible that, given the limited number of cases, the case-specific conditions (Table 5) account for the limited use of the findings, and there is no reason to expect that future cases will suffer similar limitations? Is it possible that the selection of cases was faulty? Starting with the latter, the research was based on cases for which environmental experts aimed to contribute knowledge to support decision makers and for which the existence of the gap was a realistic concern. They were also cases in which the involved experts realized that they needed interaction with 
Table 5. Main uses and explanatory conditions for the limited use of actor analysis.

\begin{tabular}{lll}
\hline \hline Case & Main use of actor analysis & $\begin{array}{l}\text { Case-specific conditions that contributed to } \\
\text { the limited use of actor analysis }\end{array}$ \\
\hline $\begin{array}{l}\text { National water } \\
\text { resources plan, Egypt }\end{array}$ & $\begin{array}{l}\text { General learning about a new perspective of } \\
\text { interdependencies among actors }\end{array}$ & $\begin{array}{l}\text { The output partly ran against the predominantly } \\
\text { hierarchic and collectivist culture in Egypt and } \\
\text { the civil engineering background of the experts }\end{array}$ \\
$\begin{array}{l}\text { Diffuse pollution, } \\
\text { Netherlands }\end{array}$ & $\begin{array}{l}\text { Confirmation of existing knowledge and new } \\
\text { insight that simultaneously emerged from other } \\
\text { sources; small contribution through learning } \\
\text { about the perceptions of other actors }\end{array}$ & $\begin{array}{l}\text { The low priority of the diffuse pollution issue } \\
\text { and other demands on experts' time made it } \\
\text { difficult to introduce significant changes }\end{array}$ \\
$\begin{array}{l}\text { River basin planning, } \\
\text { Turkey }\end{array}$ & $\begin{array}{l}\text { Quick introduction to the project area for the } \\
\text { project team and introduction of the project to } \\
\text { the actors }\end{array}$ & $\begin{array}{l}\text { The tight schedule and financial resources did } \\
\text { not leave room to deviate from project terms of } \\
\text { reference and the European Union's Water }\end{array}$ \\
$\begin{array}{l}\text { Regional water } \\
\text { management, Philippines }\end{array}$ & $\begin{array}{l}\text { Confirmation of existing project agenda, } \\
\text { confirmation/indication of the need for actor } \\
\text { education and participation }\end{array}$ & $\begin{array}{l}\text { Framework Directive } \\
\text { issues; the project management changed after } \\
\text { the actor analysis }\end{array}$
\end{tabular}

the decision makers and the wider circle of actors in the policy-making environment, even if their primary focus was on substantive analysis. Thus, one could say that these cases showed sufficient potential to expect a useful contribution from actor analysis. In fact, the analytical success of the actor analysis in these cases confirmed this expectation.

The small number of cases evaluated means that care should be taken in making generalizations from the findings. However, given the expectations at the start, the limited use of the actor analysis output that was observed in all four cases begs the question of whether this was simply a peculiarity of these cases or whether other plausible explanations can be found in the literature. However, the available literature on actor analysis does not address the issues of concern regarding utilization success in the required amount of detail. Therefore, I turned to other bodies of literature, from which at least three plausible explanatory mechanisms emerge. Even if these mechanisms were not the subject of specific in-depth investigations, they are plausible because scientific literature indicates that the mechanisms have occurred in other instances, and there is anecdotal evidence that indicates that they have also played a role in the cases discussed here.

\section{Mechanism 1: project and institutional path dependence}

The first mechanism is based on the notion that path dependencies in ongoing projects and the existing institutional system limit the possibilities for environmental experts to use the outcomes of actor analysis. This mechanism is known from various studies of institutions and institutional change (e.g., Giddens 1979, North 1993, Araujo and Harrison 2002). The existing institutions organize the way in which environmental and other policy problems are addressed. Even though the actors that are involved in natural resources management see the need for new approaches, the current structures and the existing mass of technological, cultural, and organizational components make it difficult to break the cyclical nature of the existing institutions.

The path dependence observed in the projects thus begins with the institutional setting prior to any project formulation. This was clear, for instance, in the Turkish case, in which the project aimed to introduce a river basin management planning process that was in line with the European Union's Water Framework Directive. The Water Framework Directive prescribes a detailed list of issues that 
must be included in river basin management plans and emphasizes water quality and ecological concerns. This emphasis was inherited by the Turkish project, even though a rigid application of Water Framework Directive guidelines may not have been the most appropriate way to address the water problems in the Büyük Menderes river basin.

At the project level, previous decisions and agreements introduced certain path dependencies that did not allow the involved experts to change the direction of their projects, even if new actor analysis output suggested that this might be worthwhile. Either there was no budget to include new issues and additional perspectives or the existing teams did not have the appropriate expertise to implement the proposed new directions for analysis.

\section{Mechanism 2: the preferences of experts for their own professional tools and expertise}

In addition to path dependence in existing projects and institutions, the literature on the psychology of decision making may help to explain the limited use of the actor analysis output. Literature in this field suggests that people are easily biased and selective in their information preferences, that they generally seek to avoid regret and disappointment, and that they do so through, for example, not making decisions, delaying decisions, and not changing past decisions (Janis and Mann 1977, Zeelenberg et al. 2000, Raiffa et al. 2002). For instance, Janis and Mann's (1977) conflict model for information preferences states that people are likely to become close-minded and biased in their information preferences if they perceive serious losses from changing their current behavior and if they have no hope of finding a satisfactory solution. Another part of the model states that informal social constraints and personal constraints make people reluctant to admit to themselves and to others that changes to their initial analysis designs might be required (Janis and Mann 1977).

In all four cases, the core of the project involved the use of classic engineering tools and approaches, including simulation models, spreadsheets, and decision support systems. The actor analysis output pointed to the need to incorporate new aspects into the problem analysis by calling for a more participatory approach and more attention to institutional and socioeconomic aspects; these aspects are difficult to capture using classical engineering tools. However, the actor analysis output did not give the involved experts detailed guidelines on how to incorporate these aspects. The majority of experts were not very familiar with approaches that could help them to translate these findings into actions. This left them with a stimulus for change, but without the experience or tools to do so. Thus, suggestions for additional analysis activities were sometimes echoed, but could not move the experts' attention from planned analysis activities to new fields of analysis.

\section{Mechanism 3: environmental experts as issue advocates}

The environmental experts that were involved in the cases aspired to provide information to decision makers. Heintz and Jenkins-Smith (1988) identified three dominant roles for such information providers: the objective technician, who provides neutral, objective, and comprehensive analysis; the issue advocate, who uses analysis to pursue some conception of what is good for society; and the client's advocate, who uses analyses to make the best case for their client's preferred options (Heintz and Jenkins-Smith 1988). Environmental experts often present themselves as objective technicians. They use scientific methods and rational engineering tools to analyze social-ecological systems and to provide neutral information that helps decision makers to make well-founded decisions (Dinar 1998, Norse and Tschirley 2000, Francis et al. 2005). However, empirical research suggests that experts in practice may bear a close resemblance to issue advocates. A survey by Sabatier and Zafonte (1999) related to a water policy dispute in the San Francisco Bay area indicated that the involved experts, i.e., university scientists and civil servants, had belief systems that were very similar to those of leaders of environmental and water development interest groups. This finding is echoed by other sources, including a report by some of the world's leading environmental experts: "a fundamental challenge is to change perceptions and mindsets, among actors and across all sectors of society" (International Council for Science 2002: 9).

Much to their surprise, for example, the experts in North Holland noticed that the decision makers held priorities for polluting substances that were not in line with the relative effects of those substances on the main water quality parameters. Additional 
factors other than physical cause-and-effect chains influenced their political priority setting. Nevertheless, the initial approach that the team of experts had developed for the prioritization of polluting sources remained unchanged, suggesting that the experts did not consider it worthwhile to distort their technical designs with political considerations. In the Philippines, the experts that led the project apparently found it difficult to be open to other actors' priorities and ideas; their interpretation of the actor analysis output was that a lot of actors still did not see the really important problems and that more education and information campaigns were required.

\section{Reflections on the future use of actor analysis by environmental experts}

If one accepts that there is value in my research findings and in these three explanatory mechanisms, even if the research covered only four cases and the mechanisms are no more than plausible hypotheses, what does this mean for the gap between environmental experts and decision makers and for the future use of actor analysis? My findings suggest that the future usefulness of actor analysis depends on the ability to develop responses to the mechanisms of utilization failure, including the three mechanisms described here. Unfortunately, there are no easy responses, if only because it is not easy to change institutional contexts and the mindsets and skills of people and organizations. Nevertheless, there are some seemingly small changes that may help a great deal in improving the situation. These small responses mainly require changes in the way that environmental policy analysis projects are designed. Project designs should leave some room for changes in project priorities and schedules, for instance, to allow experts to investigate some specific environmental issues that would benefit from early thorough examination. This should include room in the project's budget for the implementation of actor analysis recommendations such as for hiring the services of professionals who have specific skills in other relevant areas. De Bruijn and ten Heuvelhof (2002), Mayer and Veeneman (2002), van Eeten et al. (2002), Mostert (2003), and Pahl-Wostl (2006) suggest that in addition to economic and institutional expertise, other relevant areas would include process management, group facilitation, group model building, and serious gaming. In this way, environmental experts can access skills that are not yet present in their project teams.

A pessimist may argue that the environmental experts are not likely to develop responses such as those that I have suggested because the experts cling to their engineering tools and their preconceived ideas about the main environmental problems and solutions. However, if environmental experts are not willing to make a conscious effort to address these mechanisms when they know that various mechanisms limit their ability to close the gap between themselves and decision makers, they should not be surprised if the effects of their work on actual decision making remains a concern.

\section{CONCLUSION}

Environmental experts often express their concern over the gap between themselves and decision makers. Closing this gap requires effort on behalf of both environmental experts and decision makers, but my focus here was limited to the role of environmental experts. This is not because experts have a greater responsibility than decision makers in this regard, but simply because they regularly express the desire to narrow the gap.

Actor analysis is thought to hold the promise of helping environmental experts to identify how they could better contribute useful knowledge to ongoing policy processes. To further explore this promise, I reported the use of actor analysis in four cases in which experts aimed to provide useable knowledge to support policy processes in the field of water resources management. The conclusion from these four cases must be that actor analysis has not yet met its expectations. A plausible explanation for this negative finding is that practical barriers limit the extent to which environmental experts can use the output of actor analysis because path dependence and institutional complexities limit the room for maneuvering. Furthermore, the mindset of environmental experts seems to pose another barrier that is also important.

Connecting with decision makers not only requires decision makers to be more receptive to the knowledge of experts, but also requires experts to depart from their traditional tools and solutions and to find a compromise between their own concerns and those of decision makers. The output of actor analysis makes this very clear. The fact that the experts in the cases did not act upon the actor 
analysis output does not necessarily mean that this output is useless, but may well imply that environmental experts need to reflect on their grievances about the gap with decision makers and the role that they want to play in the policy process. Do experts really want to provide objective information on issues about which decision makers are interested or would they rather advocate the importance of environmental problems and educate ignorant societies? Do experts want to explore new participatory ways of addressing environmental problems or would they rather stick to their focus on the natural sciences and the traditional engineering approaches that have proven their usefulness in the past? Environmental experts themselves are an important driver behind the creation and preservation of their gap with decision makers. The promise of actor analysis can only truly be fulfilled if experts commit themselves to the full consequences of adaptive co-management and participatory policy making, even if the consequences reach further than many experts may currently realize.

Responses to this article can be read online at:

http://www.ecologyandsociety.org/voll3/iss1/art21/responses/

\section{Acknowledgments:}

I express my gratitude to the many people and organizations that supported the research presented here, especially Wil Thissen, Eelco van Beek, Kees Bons, and Pieter Bots. Bert Enserink, Frans Hermans, and two anonymous reviewers provided helpful comments on earlier drafts of the manuscript.

\section{LITERATURE CITED}

Araujo, L., and D. Harrison. 2002. Path dependence, agency and technological evolution. Technology Analysis and Strategic Management 14 (1):5-19.

Baskerville, G. L. 1997. Advocacy, science, policy, and life in the real world. Conservation Ecology 1 (1): 9. [online] URL: http://www.consecol.org/vol1/ iss1/art9/.
Borsuk, M., R. Clemen, L. Maguire, and K. Reckhow. 2001. Stakeholder values and scientific modeling in the Neuse River watershed. Group Decision and Negotiation 10(4):355-373.

Bots, P. W. G., M. J. W. van Twist, and J. H. R. van Duin. 2000. Automatic pattern detection in stakeholder networks. In J. F. Nunamaker and R. H. Sprague, editors. Proceedings of the 33rd Hawaii International Conference on System Sciences (CDROM) January 4-7, 2000. Computer Society Press, Manoa, Hawaii, USA. Available online at: $\underline{\text { ttp://cs }}$ dl2.computer.org/comp/proceedings/hicss/2000/04 93/02/04932016.pdf.

Brugha, R., and Z. Varvasovszky. 2000. Stakeholder analysis: a review. Health Policy and Planning 15(3):239-246.

Bryson, J. 2004. What to do when stakeholders matter. Public Management Review 6(1):21-53.

Campbell, D. T. 1988. Methodology and epistemology for social science: selected papers. E. S. Overman, editor. University of Chicago Press, Chicago, Illinois, USA.

Carrington, P. J., J. Scott, and S. Wasserman, editors. 2005. Models and methods in social network analysis. Cambridge University Press, Cambridge, UK.

de Bruijn, H. and E. ten Heuvelhof. 2002. Policy analysis and decision making in a network: how to improve the quality of analysis and the impact on decision making. Impact Assessment and Project Appraisal 20(4):232-242.

Dinar, A. 1998. Water policy reforms: information needs and implementation obstacles. Water Policy 1(4):367-382.

Dunn, W. N. 1993. Policy reforms as arguments. Pages 254-290 in F. Fischer and J. Forester, editors. The argumentative turn in policy analysis and planning. Duke University Press, Durham, North Carolina, USA.

Forester, J. 1989. Planning in the face of power. University of California Press, Berkeley, California, USA.

Francis, T. B., K. A. Whittaker, V. Shandas, A. V. Mills, and J. K. Graybill. 2005. Incorporating 
science into the environmental policy process: a case study from Washington State. Ecology and Society 10(1): 35. [online] URL: http://www.ecolog yandsociety.org/vol10/iss1/art35/.

Franklin, J. F. 1997. Commentary on Gordon Baskerville's perspective. Conservation Ecology 1 (1): 10. [online] URL: http://www.consecol.org/vol1/ iss $1 / \operatorname{art10/.}$.

Fujii, K. 1997. Commentary on Gordon Baskerville's perspective. Conservation Ecology 1 (1): 11. [online] URL: http://www.consecol.org/vol1/ iss1/art11/.

Gallopin, G. C. 1997. Commentary on Gordon Baskerville's perspective. Conservation Ecology 1 (1): 12. [online] URL: http://www.consecol.org/vol1/ iss1/art12/.

Giddens, A. 1979. Central problems in social theory: action, structure, and contradiction in social analysis. University of California Press, Berkeley, California, USA.

Goeller, B. F. 1988. A Framework for evaluating success in systems analysis. Pages 567-617 in H. J. Miser and E. S. Quade, editors. Handbook of systems analysis: craft issues and procedural choices. Wiley, Chichester, UK.

Grimble, R., and K. Wellard. 1997. Stakeholder methodologies in natural resource management: a review of principles, contexts, experiences and opportunities. Agricultural Systems 55(2):173-193.

Gunderson, L., and S. S. Light. 2006. Adaptive management and adaptive governance in the everglades ecosystem. Policy Sciences 39 (4):323-334.

Heintz, Jr., H. T., and H. C. Jenkins-Smith. 1988. Advocacy coalitions and the practice of policy analysis. Policy Sciences 21(2-3):263-277.

Hermans, L. M. 2003. Agenda setting in policy analysis: exploring conflict for a case of water resources management in the Philippines. Pages 3314-3321 in Proceedings of the IEEE International Conference on Systems, Man and Cybernetics, 5-8 October, 2003. Washington, D.C., USA.

Hermans, L. M. 2004. Dynamic actor network analysis for diffuse pollution in the province of North-Holland. Water Science and Technology 49 (3):205-212.

Hermans, L. M. 2005. Actor analysis for water resources management: putting the promise into practice. Eburon, Delft, the Netherlands. Available online at: http://www.library.tudelft.nl/ws/search/ publications/search/metadata/index.htm?docname $=347628$

Hermans, L. M., N. El-Masry, and T. M. Sadek. 2002. Linking actors and models for water policy development in Egypt: analyzing actors and their options. Knowledge, Technology, and Policy 14 (4):57-74.

Hjortso, C. N., S. M. Christensen, and P. Tarp. 2005. Rapid stakeholder and conflict assessment for natural resource management using cognitive mapping: the case of Damdoi Forest Enterprise, Vietnam. Agriculture and Human Values 22 (2):149-167.

Holling, C. S., editor. 1978. Adaptive environmental assessment and management. International Institute for Applied Systems Analysis, Laxenburg, Austria, and Wiley, Chichester, UK.

Howard, N. 1989. The manager as politician and general: the metagame approach to analysing cooperation and conflict. Pages 239-261 in J. Rosenhead, editor. Rational analysis for a problematic world: problem structuring methods for complexity, uncertainty, and conflict. Wiley, Chichester, UK.

International Council for Science. 2002. Resilience and sustainable development. ICSU Series on Science for Sustainable Development, Number 3. International Council for Science, Paris, France. Available online at: http://www.icsu.org/G estion/img/ICSU DOC DOWNLOAD/64 DD FI LE Vol3.pdf.

Janis, I. L., and L. Mann. 1977. Decision making: a psychological analysis of conflict, choice, and commitment. Free Press, New York, New York, USA.

Kilgour, D. M., and K. W. Hipel. 2005. The graph model for conflict resolution: past, present, and future. Group Decision and Negotiation 14 (6):441-460. 
Kontogianni, A., M. S. Skourtos, I. H. Langford, I. J. Bateman, and S. Georgiou. 2001. Integrating stakeholder analysis in non-market valuation of environmental assets. Ecological Economics 37 (1):123-138.

Levin, S. A. 1997. Management and the problem of scale. Conservation Ecology 1(1): 13. [online] URL: http://www.consecol.org/vol1/iss1/art13/.

Mayer, I., and W. Veeneman, editors. 2002. Games in a world of infrastructures: simulationgames for research, learning and intervention. Eburon, Delft, the Netherlands.

Mostert, E. 2003. The challenge of public participation. Water Policy 5(2):179-197.

Mouratiadou, I., and D. Moran. 2007. Mapping public participation in the Water Framework Directive: a case study of the Pinios River basin, Greece. Ecological Economics 62(1):66-76.

Norse, D., and J. B. Tschirley. 2000. Links between science and policy making. Agriculture, Ecosystems and Environment 82(1-3):15-26.

North, D. C. 1993. Institutional change: a framework of analysis. Pages 35-46 in S.-E. Sjöstrand, editor. Institutional change: theory and empirical findings. M. E. Sharpe, New York, New York, USA.

Pahl-Wostl, C. 2006. The importance of social learning in restoring the multifunctionality of rivers and floodplains. Ecology and Society 11(1): 10. [online] URL: http://www.ecologyandsociety.org/vol11/ iss1/art10/.

Pulliam, H. R. 1997. Bridging the gap between ecology and resource management. Conservation Ecology 1(1): 14. [online] URL: http://www.consec ol.org/vol1/iss 1/art14/.

Raiffa, H., J. Richardson, and D. Metcalfe. 2002. Negotiation analysis: the science and art of collaborative decision making. Belknap Press of Harvard University Press, Cambridge, Massachusetts, USA.

Roux, D. J., K. H. Rogers, H. C. Biggs, P. J. Ashton, and A. Sergeant. 2006. Bridging the science-management divide: moving from unidirectional knowledge transfer to knowledge interfacing and sharing. Ecology and Society 11(1): 4. [online] URL: http://www.ecologyandsociety.org/vol11/iss 1/ $\underline{\operatorname{art} 4 / .}$

Sabatier, P., and M. Zafonte. 1999. Are bureaucrats and scientists members of advocacy coalitions? Evidence from an intergovernmental water policy subsystem. Pages 25-73 in S. L. Hsu, editor. Economic Research and Policy Concerning Water Use and Watershed Management: Proceedings of the Third Workshop in the Environmental Policy and Workshop Series. 21-22 April, 1999. U. S. Environmental Protection Agency, Washington, D. C., USA. Available online at: http://es.epa.gov/ncer/ publications/workshop/pdf/EE-0423-04.pdf.

Scharpf, F. W. 1997. Games real actors play: actorcentered institutionalism in policy research. Westview Press, Boulder, Colorado, USA.

Scott, J. 2000. Social network analysis: a handbook. Second edition. Sage, London, UK.

Stone, H. L. 2002. Graphically modeling stakeholder values. Journal of the American Water Resources Association 38(4):1019-1026.

Toulmin, S. E. 1958. The uses of argument. Cambridge University Press, Cambridge, UK.

van de Riet, O. A. W. T. 2003. Policy analysis in multi-actor policy settings: navigating between negotiated nonsense and superfluous knowledge. Eburon, Delft, the Netherlands.

van Eeten, M. J. G., D. P. Loucks, and E. Roe. 2002. Bringing actors together around large-scale water systems: participatory modeling and other innovations. Knowledge, Technology, and Policy 14 (4):94-108.

Walker, B. 1997. Commentary on Gordon Baskerville's perspective. Conservation Ecology 1 (1): 15. [online] URL: http://www.consecol.org/vol1/ iss1/art15/.

Wiens, J. A. 1997. Scientific responsibility and responsible ecology. Conservation Ecology 1(1): 16. [online] URL: http://www.consecol.org/vol1/iss1/ art16/.

Wildavsky, A. 1979. Speaking truth to power: the art and craft of policy analysis. Little and Brown, 
Boston, Massachusetts, USA.

Zeelenberg, M., W. W. van Dijk, A. S. R. Manstead, and J. van der Pligt. 2000. On bad decisions and disconfirmed expectancies: the psychology of regret and disappointment. Cognition and Emotion 14(4): 521-541. 